ppi $201502 Z U 4645$

Esta publicación científica en formato digital es continuidad de la revista impresa ISSN-Versión Impresa 0798-1406 / ISSN-Versión on line 2542-3185Depósito legal pp $197402 Z$ U34

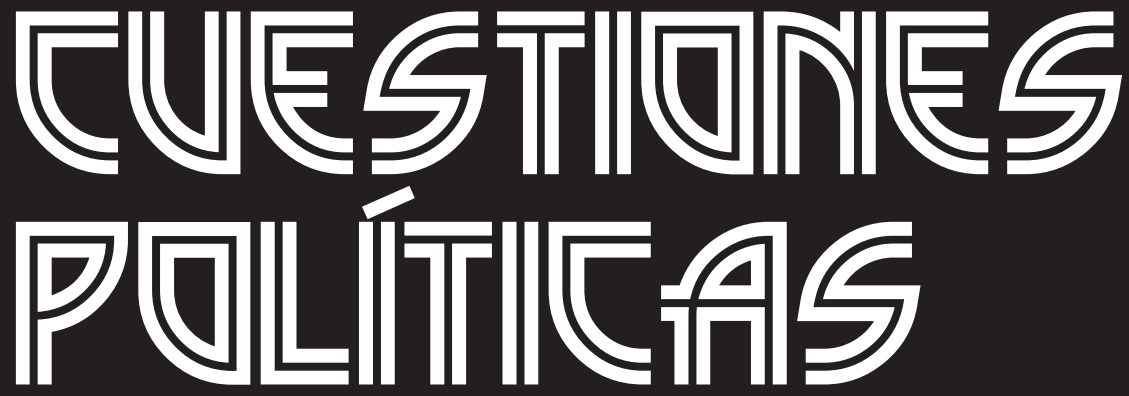

Instituto de Estudios Políticos y Derecho Público "Dr. Humberto J. La Roche" de la Facultad de Ciencias Jurídicas y Políticas de la Universidad del Zulia Maracaibo, Venezuela
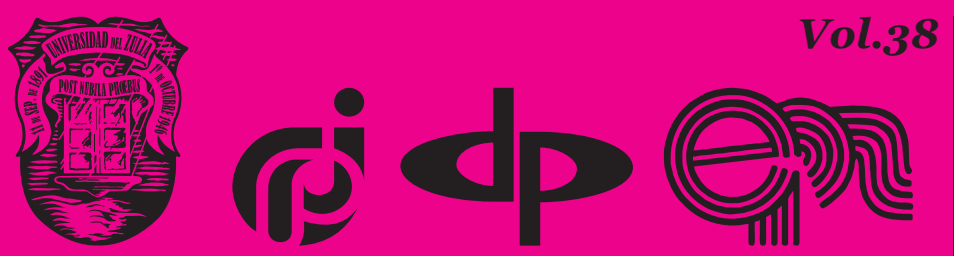

$N^{\circ}$ Especial 1era Parte 2020 


\title{
Rethinking Tourism Public Policies to mitigate the effects of Covid-19
}

\author{
DOI: https://doi.org/10.46398/cuestpol.38e.o8
}

\author{
Cynthia Milagros Apaza-Panca * \\ Johanna Elena Santa-Cruz Arévalo ** \\ Pedro Jesús Maquera-Luque *** \\ Lucio Ticona-Carrizales
}

\begin{abstract}
The objective of the research was to examine and analyze the articles that address public tourism policies in specialized magazines at a global level, with the aim of knowing through comparative public policies, alternative solutions in a postpandemic scenario. Regarding the methodology, articles were selected whose titles presented one or more keywords that referred to the disease "Covid-19" and "public tourism policies" in Spanish and English. To process the information, the content analysis technique was used. The results showed that the place and space occupied by tourism public policies in the main tourism magazines is scarce and not seen as a management tool for the sector. The conclusion emphasized the lack of clarity regarding the methodology used in the articles and the scarce proposal of public policies that were implemented in situations of health crises, epidemics, wars, etc. For the rest, the following questions served as a guide for the analysis: 1) What is the role of governments in the tourism sector? and, 2) What public policies did governments implement in similar
\end{abstract} situations such as the current health crisis?

Keywords: COVID-19; public policies in tourism; tourism; scientific publications on tourism; health crisis.

* $\quad$ Master Scientiae in Economics. Research Professor. Frontera National University. ORCID ID: https:// orcid.org/oooo-0oo2-5524-2627. Email: capaza@unf.edu.pe

** Master's in education. Professor Frontera National University. ORCID ID: https://orcid.org/ooooo003-0213-5534. Email: jsantacruz@unf.edu.pe

*** Doctor in Public Management, Doctor in Educational Administration. Principal Professor. Moquegua National University. ORCID ID: https://orcid.org/oooo-0002-2490-8879. Email: pmaqueral@unam. edu.pe

**** Doctor in Economics and Public Policy, Doctoris Scientiae in Sciences, Technology and Environment. Principal Professor. Juliaca National University. ORCID ID: https://orcid.org/oooo-0001-6625-1396. Email: l.ticonac@unaj.edu.pe 
Cynthia Milagros Apaza-Panca, Johanna Elena Santa Cruz Arévalo, Pedro Jesús Maquera-

Luque y Lucio Ticona-Carrizales

120

Rethinking Tourism Public Policies to mitigate the effects of Covid-19

\section{Repensando las Políticas Públicas de Turismo para mitigar los efectos del Covid-19}

\section{Resumen}

El objetivo de la investigación fue examinar y analizar los artículos que abordan las políticas públicas de turismo en revistas especializadas a nivel global, con la finalidad de conocer por medio de políticas públicas comparadas, alternativas de solución en un escenario de pospandemia. En cuanto a la metodología, se seleccionaron artículos cuyos títulos presentaban una o más palabras clave que se referían a la enfermedad del "Covid-19" y "políticas públicas de turismo" en español e inglés. Para procesar la información se utilizó la técnica de análisis de contenido. Los resultados mostraron que el lugar y el espacio ocupado por las políticas públicas de turismo en las principales revistas de turismo es escaso y no visto como una herramienta de gestión para el sector. La conclusión enfatizó la falta de claridad en cuanto a la metodología utilizada en los artículos y la escasa propuesta de políticas públicas que se implementaron en situaciones de crisis sanitarias, epidemias, guerras, etc. Por lo demás, las siguientes preguntas nos sirvieron como guía para el análisis: 1) ¿Cuál es el rol de los gobiernos en el sector turismo? y, 2) ¿Qué políticas públicas implementaron los gobiernos en situaciones similares como la crisis sanitaria actual?

Palabras clave: COVID-19; políticas públicas en turismo; turismo; publicaciones cientificas sobre turismo; crisis sanitaria.

\section{Introduction}

In late December 2019, an unknown pneumonia outbreak of etiology occurred in Wuhan, Hubei Province, China, and rapidly spread throughout the country. The Chinese Center for Disease Control and Prevention (CCDC) identified a new beta-coronavirus called 2019-nCoV, now officially known as severe acute respiratory syndrome coronavirus 2 (SARS-CoV-2), which has become a global threat because of its quick spread, thus becoming a public health problem (Xie y Chen, 2020) causing a large number of deaths with tens of thousands confirmed cases mounting to rise around the world (Sun al., 2020). On January $12^{\text {th }} 2020$, the World Health Organization (WHO) temporarily named this recent virus as the new coronavirus 2019(2019-nCoV). On 11th February 2020, WHO officially named the disease caused by 2019-nCoV as coronavirus disease (COVID-19) (Sun et al., 2020). Since then, the World Health Organization (WHO) data have shown that more than 43 ooo confirmed cases have been identified in 28 countries; becoming this way the sixth public health emergency of 
international concern (Lai et al., 2020); and therefore a real threat to global health given by the continuing outbreak of the disease (Fauci et al., 2020). In addition, as a complex respiratory disease never experienced before and with a spreading ability and successful infection, it grabbed the world's attention but without a treatment and control manual (Suganthan, 2019). At a higher risk of developing the disease has led many governments to implement a series of control measures (Harapan et al., 2020), on a trialand-error basis. It is worth noting that the impact of Ebola epidemic on the economy and health care structures was still felt five years later in the countries concerned (Velavan y Meyer, 2020); meeting the challenge of a pandemic, the picture, of course, it is an outlook of uncertainty.

As a result, economies have become vulnerable and therefore shut down, and societies are quarantined to varying degrees, comparable measure to those in war situations. It will nevertheless always be essential for the State to support planning activities which must be confined to facilitating the conditions required to hold and involves both supply- and demand-orientated measures. On the one hand, it will require to develop and strengthen the capacities of public authorities, resources and policy instruments responsible for designing a very high productive capacity in each country in an attempt to safeguard the installed capacity. On the other hand, the lack of protection for the poorest strata and their difficulty in gaining access the right to satisfaction of basic needs have already sparked social unrest in some countries.

\section{Literature Review}

Covid-19 will be associated with serious short and long-term adverse effects on supply, demand and including at sectoral levels. The intensity and extent of which will depend on household's conditions in each economy, global trade, epidemic length, and the social and economic measures taken to keep it from spreading; tourism will be remained one of the most affected. In Latin America, the economic impacts of the Covid-19 pandemic are quoted as direct and indirect. Direct impacts will be fully reflected on health systems, given the colossal burden on broken systems and unequal access pertaining to income levels and place of residence. Indirect impacts will be reflected for the closure of production: education, trade, tourism, transportation, manufacturing, natural resources; on the premise that all of these will bring about a global recession and driving up unemployment.

In the same vein, medium- and long-term impacts will be displayed such as bankruptcies, downsizing private investment, a low level of economic growth, less integration into value chains, erosion of productive capacities and human resources. Furthermore, short-term impacts such as higher 
Cynthia Milagros Apaza-Panca, Johanna Elena Santa Cruz Arévalo, Pedro Jesús MaqueraLuque y Lucio Ticona-Carrizales

unemployment, low wages and income, increased poverty, and extreme poverty (Economic Commission for Latin America and the Caribbean, 2020). In 2019, the worst world economy performance was registered since 2009, with a growth rate of only 2.5\%. On March 24th 2020, Goldman Sachs' annual forecast indicated Gross Domestic Product (GDP) would decline of 3.8\% in the United States, 9\% in the Eurozone and 2.1\% in Japan, and a serious downturn in Chinese economy that would lead to growth of only 3\% (Goldman Sachs, 2020).

Thereby having a negative impact on employment wages, and income distribution; therefore, all firms, regardless of size, are and will be affected, especially those in transport, tourism, and services such as retail. Many are already dealing with a significant decrease in income, insolvencies and resulting in the loss of many jobs in specific sectors, in which labor market would ensue irrevocable impact.

What is more, Covid 19 crisis will hasten some structural changes which broke up in the last decade. For instance, forced quarantine will increase the virtualization of economic and social relations; teleworking shall prevail in more industries and regions; and digitalization will be sought more quickly. Within this framework, the most technologically advanced companies will be able to increase their advantages over those companies, MiPymes, which are lagging ever further behind. High-tech companies have already boosted their use of artificial intelligence tools to cope with the lack of workers due to quarantines.

The coronavirus will therefore affect the number of jobs (increased unemployment and underemployment), quality work (reduced wages and access to social protection) and the most vulnerable groups, such as informal workers. Loss work-related income will result in a decreasing consumption of goods and services and would lead many workers into poverty. The very vulnerable group people would feel the unbalanced impact due to the existence crisis: unhealthy people, elder people, unemployed youth, underemployed people, women, workers without biosafety equipment, migrant workers by heading a secondary effect by worsen inequality. Meanwhile, Latin America and the Caribbean surely face the pandemic at their weakest position than the rest of the world. Before this context, Economic Commission for Latin America, and the Caribbean (ECLAC) had forseen these regions would increase of $1.3 \%$ by 2020 . However, reports have been updated and since external and domestic shocks have intensified the region will experience a -1.8\% (Economic Commission for Latin America and the Caribbean, 2020).

It should be noted that, in developing countries, the level of informality makes it difficult to distance oneself from society, regardless of the type of occupation, the informal working arrangements makes it more difficult for the poor to shelter in their house. Many workers have no access to sick leave 
or unemployment benefits, they barely have poor access to health benefits, and their savings are non-existent or extremely limited. Most informal workers experience living their lives with a minimum of resources. The lack of sound income maintenance policies, for many of these workers staying at home is not considered as a feasible option at this time (Busso and Messina, 2020).

There are two indicators about informality work. The first indicator: informal workers do not have access to healthcare or pension benefits through their jobs. The second one: the growing share of self-employed workers mainly with a low education. In Bahamas, Chile, Costa Rica and Uruguay, over two-thirds have the described characteristics above, therefore no one either of these employees is well-trained or prepared to withstand a prolonged solitary confinement (Busso \& Messina, 2020). According to Nuguer and Powel (2020) Chinese industrial sector appears to be picking up. Looking ahead, consumption and services sectors are expected to positively be recovering. It will likely happen enormous drawbacks and even further outbreaks through this period which strictly control would be needed. Fiscal and monetary sector will support advanced economies but creating a great deal of uncertainty about loss and the speed at which recovery can take them; in particular, the most vulnerable sector as tourism.

During years, academic researches about tourism was looked to as "frivolous" and seemed as inappropriate for the scholars (Matthews y Richter, 1991:121). However, it is clear that there is a significant need to mesh tourism policies and social science techniques with skills and other competences required by tourism professionals (Matthews y Richter, 1991:133) to cope with this current crisis; particularly when mass tourism is understood as responsible for wreaking social, cultural, economic and environmental havoc in its path, and its practices must be radically changed to introduce a new proposal (Garnham, 1995).

Notwithstanding, tourism has a high economic importance in many countries. In Italy, tourism is considered as a strategic industry which represents $6 \%$ of the total value added and employing approximately $10 \%$ of the total workforce (Matthews y Richter, 1991:140); there is, of course, enough to talk about tourism, in turn, it implies a package of complex services, turning this into an great experience which requires a wide vary of conditions which would be needed simultaneously satisfied. On the other hand, tourist services has its own features so turning it into an attractive potential source of revenues, employment and new possibilities in the field of service innovation, in view especially of the fact that this would be an experience that might be continuously based on knowledge and technology management (Benavides, 2015a).

People travel abroad for different reasons which imply vacations, business, scholarly work, religious issues, sport or artistic work, medical 
Cynthia Milagros Apaza-Panca, Johanna Elena Santa Cruz Arévalo, Pedro Jesús MaqueraLuque y Lucio Ticona-Carrizales

treatment (Arif y Hall, 2019:276). And, although it is true that global changes, matched by the need for solid economic activities, have enhanced some families to recourse to tourism as an economic diversification strategy for instance rural tourism (Iorio y Corsale, 2010).

Thus, a fundamental part of the government's role is the design, management, and evaluation of public policies (Lahera, 2004). Mexican tourist policies were focused on priority areas for economic development and to cover the increase in investment needed for them in this respect. They are evaluation of the current development model, suggestions for policy design and strengthening governance, as well as improvements in transport systems, mobility and connectivity for tourist travel; inclusive growth, regional and new destination development; product diversification; investment and strengthening of PyMEs (OECD, 2017).

In the 9os, conventional model of tourism broke up a crisis, alternative tourism started growing and due mainly to the increasing concerns about the environment, Mexico has incorporated the dimension of sustainability as a main element in the development of ecotourism, in which indigenous peoples and communities found an economic alternative that, at the same time it would help them both to preserve natural and cultural heritage, change the subordinate and dependent relationship in national market (López Pardo y Palomino Villavicencio, 2008). In addition, rural innovation programs have shown a significant increase in supply at various levels: rural accommodation rising, rehabilitation of heritage, value enhancement of historical elements, in short, of the historical, cultural, architectural and natural heritage of the rural world.

Background named "identity crisis" was used in Hong Kong postcolonial period, its complex century-old socio-cultural political heritage let express a different identity from China through tourism (Zhang et al., 2015). Colombian tourism have become very powerful alternative way of doing business as a result of a strategic planning, institutional presence in the sector, spawning a regulatory framework, incentive mechanisms and in terms of attracting foreign direct investment (FDI), which has led the sector to significant progress in travel and tourism revenues in the balance of payments; and which is a good evidenced by the public policy on tourism (Benavides, 2015b).

Likewise, cultural tourism policy in Colombia highlights the potential of tourism to articulate processes of identification, valuation, competitiveness, sustainability, and dissemination of cultural heritage. It also encourages locals and foreigners to learn about it and feeling the belonging of the customs and tangible and intangible heritage of the visiting country (Karimi et al., 2018). 


\section{Comparative Tourism Public Policies}

In the U.S.A. public policies background dates back to the 40 and 50 . They emerged after World War II and with the concern that there would be a reversal of economic growth (Pereira, 1999). Almost all governments, at all levels, claim to have a tourism policy and this topic is named in election periods and government ones. A lot of governments make their efforts on promoting it, but little do they have on tourism policies.

Tourism policy could be understood as a set of actions by government entities, with the purpose of changing the current economic and social environment. In general, policies, in every country, set the essential activity guidelines, the objectives and action- state priorities for the sector (Lopes, et al., 2011). Therefore, tourism policy must consider the different stakeholders, products, impacts and so on; since only a program focused on a specific touristic typology or on a specific sub-sector would not be a good and effective policy. Although this does not mean that a government cannot promote a tourism policy through various specific programs. Reaffirming that tourism policy is the set of actions which is promoted by public actors in order to solve the public problems of the sector (Velasco González, 2011).

Tourism is the world's largest industry so it should lead the changes towards greater sustainability. For instance, there can be no delay in taking advantage of new opportunities on climate changing such as $\mathrm{CO} 2$ capture primarily due to travel, this would help to turn tourist destinations into favor of carbon neutral sites through the implementation of alternative energy processes and the promotion of carbon sequestration by natural means. This would allow local income through natural regeneration and ecosystem restoration like Costa Rica which has plans on carbon neutral country.

It is also important to say any attempt or strategy to develop tourism must start through the processes of self-esteem recovery, value of the environmental setting and its own culture at local level. Therefore, the more secure and proud a person is of their own identity, the less likely it is to have negative cultural and social impacts; thus, including the civil recovery and love of the homeland. Culture must be valued for what means to community and the preservation of its customs and values, and not merely for a given tip. Priority should be given to the continuous improvement of the quality of life of local populations. People from all society sectors must be incorporated, taking into account youth, the elderly, any gender and minority groups. Intersectoral coordination strategies must be clearly established (Müller, 2008).

As a first step, governments must stimulate tourism sector by creating the tourism offer and providing the infrastructure required to start it; at 
Cynthia Milagros Apaza-Panca, Johanna Elena Santa Cruz Arévalo, Pedro Jesús MaqueraLuque y Lucio Ticona-Carrizales

the same time, it is the one that must promote the country both internally and externally as a tourist destination (Benavides, 2015a), given the current circumstances due to the health crisis.

\subsection{Tourism Policy Aims}

\section{Governments have focused on different themes over the past sixty years:}

\section{Table 1. Tourism policy aims}

\begin{tabular}{|c|c|c|c|}
\hline Related to tourists & $\begin{array}{l}\text { Related to tourist } \\
\text { business }\end{array}$ & $\begin{array}{l}\text { Related to tourist } \\
\text { destinations }\end{array}$ & $\begin{array}{c}\text { Related to } \\
\text { outstanding issues }\end{array}$ \\
\hline $\begin{array}{l}\text { - Taking forward } \\
\text { improvements and } \\
\text { speed up border- } \\
\text { crossing and } \\
\text { transit formality } \\
\text { procedures. } \\
\text { - Tourism consumer } \\
\text { protection (tourist as } \\
\text { a service consumer } \\
\text { has trouble with } \\
\text { the local language } \\
\text { and misunderstand } \\
\text { cultural customs in } \\
\text { their destination) }\end{array}$ & $\begin{array}{l}\text {-Encourage the } \\
\text { creation of small } \\
\text { and medium-sized } \\
\text { tourism enterprises } \\
\text { and support their } \\
\text { innovation. } \\
\text {-Training is needed } \\
\text { in order to provide } \\
\text { female and male } \\
\text { employees in the } \\
\text { tourism enterprises. } \\
\text {-Financing } \\
\text { facilities to boost } \\
\text { entrepreneurial } \\
\text { activity, new } \\
\text { products so this } \\
\text { diversify the touristic } \\
\text { offer. } \\
\text {-Domestic legislation } \\
\text { in subsectors. }\end{array}$ & $\begin{array}{l}\text {-Action must be } \\
\text { undertaken to } \\
\text { promote countries } \\
\text { in the international } \\
\text { market. } \\
\text {-Channelling tourist } \\
\text { flows through } \\
\text { the provision of } \\
\text { infrastructure. } \\
\text {-Actions must } \\
\text { be taken in } \\
\text { support of tourist } \\
\text { destinies which } \\
\text { were successful in } \\
\text { the past decades } \\
\text { and they are in } \\
\text { stagnation process } \\
\text { and obsolescence } \\
\text { now. } \\
\text {-Public - private } \\
\text { cooperation to } \\
\text { improve tourism } \\
\text { policies design. }\end{array}$ & $\begin{array}{l}\text {-Lack of planning } \\
\text { tools which need } \\
\text { to be encouraged } \\
\text { to the extent } \\
\text { compatible with } \\
\text { tourism developing. } \\
\text {-Negative impacts } \\
\text { in the environment. } \\
\text {-Lack of expertise } \\
\text { and information. }\end{array}$ \\
\hline
\end{tabular}

Source: (Velasco Gonzáles, 2014).

\section{Table 2. Challenges and commitments in South American tourism}

Argentina

Brasil
Development of a market policy to guide and coordinate the dispersed and dissociated factors to foster quality and efficiency required by a highly competitive global environment in a limited internal scenario.

The tourism sector's business informality, low professionalism, high taxes, lack of flexibility in issuing visas for developed countries and the strong value of local currency. Investments are needed in airport infrastructure, hospitality and training. 


\begin{tabular}{|c|c|}
\hline Chile & $\begin{array}{l}\text { The high seasonal fluctuation reduces to a seven-month tourist season per } \\
\text { year. This scenario is made even more acute by the high cost of airfares over } \\
\text { long distances to leading European, Asian, North American emitters. There } \\
\text { is also a significant factor that influence on Chilean tourism which is low } \\
\text { population density, this does not let create a national domestic market to } \\
\text { support strongly tourism local industry. }\end{array}$ \\
\hline Perú & $\begin{array}{l}\text { Lack of a vigorous state policy as an obstacle to tourism development in } \\
\text { the country. Tourism must be assessed in order to define market niches } \\
\text { which they can work and determine their competitive advantages. Cultural } \\
\text { tourism has its own won condition. Even though others market niches could } \\
\text { likely be developed such as ecoturism, rural tourism and mystical one. } \\
\text { Peruvian tourism sector is expected to incentive and encourage domestic } \\
\text { tourism, micro tourism routes in particular, also called short routes. These } \\
\text { ones foster initiatives to increase touristic awareness and many people can } \\
\text { afford them due to their low cost. }\end{array}$ \\
\hline $\begin{array}{c}\text { Temas } \\
\text { transversales }\end{array}$ & $\begin{array}{l}\text { la cuestión del turismo sostenible y responsable es uno de los puntos } \\
\text { críticos por resolver y un gran obstáculo para el desarrollo del turismo en el } \\
\text { medio y largo plazo. } \\
\text { A lot of Latin American touristic destinations are positioning themselves as } \\
\text { nature tourism. } \\
\text { sustainable and responsible tourism is a critical issue to solve and even is } \\
\text { considered as a great drawback to develop tourism in a medium and long } \\
\text { term. }\end{array}$ \\
\hline
\end{tabular}

In the same way, some solutions were proposed for tourism microbusinesses in Ecuador where women assumes a meaningful role, such as: supporting women-training to foster their integration into labor market, employment policies in local tourism planning, search from handicrafts market; boosting training due to improve touristic handicraft production, encourage and support rural community tourism development by improving local private homes to make them suitable for tourist accommodations, borrow money at low rates on the capital markets, settle a municipal fund office for microenterprises, creating a Microenterprise Chamber and defining tourism policies with gender equity according to each local reality and national guidelines (Ordóñez Andrade \& Marco Navarro, 2005).

European policies focus on rural development have had a particular impact on promoting tourism; and above all, LEADER initiative since it started to operate, it became a rural tourism program boosting. At first, this program was applied to less-developed regions and also vulnerable rural areas. Even though, this one covered throughout Spain. Therefore, GAL (in Spanish) which stands for Local Action Groups were formed in charge of managing territorial development (Cánoves, et al., 2006).

In Mexico, in the early 6os, there was a break on tourism policies given by the government. However, at the end of 6os, things would change in the federal government. Mexican government asked the Mexican Bank to implement a policy that would promote tourism in the country. In this 
Cynthia Milagros Apaza-Panca, Johanna Elena Santa Cruz Arévalo, Pedro Jesús MaqueraLuque y Lucio Ticona-Carrizales

way, Mexico applied two strategies in some coastal areas: on the one hand, credits were granted for the infrastructure construction in beach resorts such as Acapulco, Guerrero and to a lesser extent Puerto Vallarta, Jalisco, Manzanillo, Colima and Veracruz Port and others. On the other hand, the second strategy focused on promoting investment and tourism through Integrally Planned Resort Centers (Bringas, 1999).

Today, government's challenge could be seen as the search reconcile these two dimensions: tourism normative and institutional with policy management so this would lead to a better fair distribution of social, economic and political benefits by increasing the quality of services and goods (Pereira, 1999).

\section{Methodology}

Keywords such as "Covid - 19" and "tourism public policies were searched based on publications in high impact journals, official's documents and a few updated studies. Technique of content analysis was applied (Snyder, 2019). A literature search was also conducted by Mendeley and Google Scholar which included "public policies", and "tourism public policies" and "Covid-19" in both languages: Spanish and English.

Therefore, this research provides an overview of the literature concerning public policies, and specifically one of the sectors most affected by the pandemic, tourism. It also shows the efforts made by governments to implement public policies in the sector. However, the effort to address in view of the current health crisis caused by Covid-19 disease requires swift and effective responses or design and implement post-pandemic public policies which they will remain both urgent and overwhelming.

\section{Results Analysis}

Content related to the current situation resulting from "Covid-19" disease pandemic was identified and analyzed. To start with, different ways in which tourism public policies in are referred to were identified, this has been noticed there is scarce information about the topic in scientific journals and official documents, and it is found not to be a management tool for tourism sector. Likewise, there was a plurality of authors and institutions and little use of specialized bibliography.

From "Covid-19" content, the characteristics and impacts that have been and will be occurring in the post-pandemic stage are elucidated. Information 
must be useful for governments, in order to be considered in the economic recovery plans for more than 150 countries affected throughout the world (Arroyo, 2020). In this context, governments have no pospandemic tourism public policies. However, there is great concern and uncertainty about this sector. Nonetheless, Covid-19 affected countries and even more countries with pre-existing tourism resources need to begin designing tourism public policies in order to mitigate pandemic adverse impacts and effects.

\section{Conclusion}

The lack of clarity in the methodology used in the scientific articles and official documents, which were worked with, was highlighted in this research. Furthermore, there no is evidence of implemented public policies in comparable situations such as health crises, epidemics, wars and so on.

Tourism public policies govern how a destination should be and look like, so the guidelines will say how to work, how to grow, determine where to focus and way to turn, so a proactive and active role of governments in the tourism sector is essential and crucial in a post-pandemic scenario.

Post-pandemic tourism public policies must be according to the local context due to different realities and the level of recovery of each place, taking into account that tourists are constantly on the lookout for companies that promote health care. There will also be people segments more predisposed to be appealed to have virtual experiences such as demanding for online shopping, virtual training and assistance and addressed within the preference for concerned companies about having the welfare of their customers at heart.

\section{Bibliographic References}

ARIF,I;HALL,J.C. 2019. "International flows of peopleandinstitutional change" In: European Journal of Political Economy. Available online. In: https:// www.sciencedirect.com/science/article/abs/pii/So176268017302148. Consultation date: 12/04/2020.

ARROYO, Jesús. 2020. "Coronavirus: mapa de la OMS en vivo con casos, muertes y países afectados" In: Redacción Medica. Available online. In: https://www.redaccionmedica.com/secciones/sanidad-hoy/ coronavirus-mapa-oms-en-vivo-casos-muertes-paises-afectados-8538. Consultation date: 22/03/2020. 
Cynthia Milagros Apaza-Panca, Johanna Elena Santa Cruz Arévalo, Pedro Jesús MaqueraLuque y Lucio Ticona-Carrizales

BENAVIDES, Giovanny Fernando. 2015a. "Las políticas públicas del turismo receptivo colombiano" In: Suma de Negocios. Available online. In: http://dx.doi.org/10.1016/j.sumneg.2015.08.005. Consultation date: 16/12/2019.

BRINGAS RÁBAGO, Nora L. 1999. "Políticas de desarrollo turístico en dos zonas costeras del Pacífico mexicano" In: Región y Sociedad. No. 9, Vol. 17 , pp. 3-52.

BUSSO, Matías; MESSINA, Julián. 2020. Distanciamiento social, informalidad y el problema de la desigualdad. Available online. In: https://blogs.iadb. org/ideas-que-cuentan/es/distanciamiento-social-informalidad-y-elproblema-de-la-desigualdad/. Consultation date: 22/04/2020.

CÀNOVES VALIENTE, Gemma; VILLARINO PÉREZ, Montserrat; HERRERA, Luis. 2006. "Políticas Públicas, Turismo Rural y Sostenibilidad: Difícil Equilibrio” In: Boletín de la Asociación de Geógrafos Españoles. No. 41, pp. 199-220.

ECONOMIC COMMISSION FOR LATIN AMERICA AND THE CARIBBEAN. 2020. "Latin America and the Carribbean and the COVID-19 pandemic" In: Economic and social effects. Available online. In: https:// eulacfoundation.org/en/content/latin-america-and-caribbean-andcovid-19-pandemic. Consultation date: 22/04/2020.

FAUCI, A. S; LANE, H. C; Redfield, R. R. 2020. "Covid-19 - Navigating the Uncharted" In: The New England journal of medicine. Available online. In: doi: 10.1056/NEJMe2002387. Consultation date: 29/03/2020.

GARNHAM, Bod. 1995. "Tourism, Technology and Competitive Strategies by A. Poon" In: New Zealand Geographer. Available online. In: https:// doi.org/10.1111/j.1745-7939.1995.tbo2057.x. Consultation date: 29/03/2020.

GOLDMAN SACHS. 2020. Roaring into recession. Available online. In: https:// www.goldmansachs.com/insights/pages/roaring-into-recession.html. Consultation date: 29/04/2020.

HARAPAN, Harapan; ITOH, Naoya; YUFIKA, Amanda; WINARDI, Wira; KEAM, Synat; TE, Haypheng; MEGAWATI, Dewi; HAYATI, Zinatul; WAGNER, Abram L; MUDATSIR, Mudatsir. 2020. "Coronavirus disease 2019 (COVID-19): A literature review" In: Journal of Infection and Public Health. Available online. In: https://doi.org/10.1016/j. jiph.2020.03.019. Consultation date: 27/04/2020.

IBARRA MORALES, Luís Enrique; CASAS MEDINA, Emma Vanessa. 2015. "Aplicación del modelo Servperf en los centros de atención Telcel, 
Hermosillo: una medición de la calidad en el servicio" In: Contaduría y Administración. Vol. 60, No. 1, pp. 229-260.

IORIO, Monica; CORSALE, Andrea. 2010. "Rural tourism and livelihood strategies in Romania" In: Journal of Rural Studies. Available online. In: https://doi.org/10.1016/j.jrurstud.2009.10.006. Consultation date: 27/04/2020.

KARIMI, Zahra; BATMANI, Yazdan: KHOSROWJERDI, Mohammad Javad. 2018. "Política de Turimso Cultural" In: Optimal Control Applications and Methods. Available online. In: https://doi.org/10.1002/oca.2433. Consultation date: 04/04/2020.

LAHERA, Eugenio. 2004. "Política y políticas públicas" In: CEPAL Serie Políticas Sociales. Available online. In: https://www. fundacionhenrydunant.org/images/stories/biblioteca/ Politicas-Publicas / Pol\%E2\% 94\% 9C\%C2\%A1tica\% 20 \% \% 20 pol\%E2\%94\%9C\%C2\%A1ticas\%20p\%E2\%94\%9C\%E2\%95\%91blicas. pdf. Consultation date: 04/04/2020.

LAI, Chih-Chen; SHIH, Tzu-Ping; KO, Wen-Chien; TANG, Hung-Jen; HSUEH, Po-Ren. 2020. "Severe acute respiratory syndrome coronavirus 2 (SARS-CoV-2) and coronavirus disease-2019 (COVID-19): The epidemic and the challenges" In: International Journal of Antimicrobial Agents. Available online. In: https://doi.org/10.1016/j.ijantimicag.2020.105924. Consultation date: 02/04/2020.

LI, Heng; LIU, Shang-Ming; YU, Xiao-Hua; TANG, Shi-Lin; TANG, Chao-Ke. 2020. "Coronavirus disease 2019 (COVID-19): current status and future perspectives" In: International Journal of Antimicrobial Agents. Agents. Available online. In: https://doi.org/10.1016/j.ijantimicag.2020.105951. Consultation date: 02/04/2020.

LOPES, A; TINÔCO, D; SOUZA, L. 2011. "Evaluación de políticas públicas de turismo: un análisis bibliométrico de revistas turísticas" In: Revista Turismo Em Análise, Vol. 22, No. 3, pp. 614-631.

LÓPEZ PARDO, Gustavo; PALOMINO VILLAVICENCIO, Bertha. 2008. "Políticas públicas y ecoturismo en comunidades indígenas de México" In:Teoría y Praxis. Available online. In: http://www.nacionmulticultural. unam.mx/empresasindigenas/docs/24.pdf. Consultation date: 16/04/2019.

MATTHEWS, Harry G; RICHTER, Linda K. 1991. "Political science and tourism" In: Annals of Tourism Research. Available online. In: https://doi. org/10.1016/0160-7383(91)90043-B. Consultation date: 16/04/2019. 
Cynthia Milagros Apaza-Panca, Johanna Elena Santa Cruz Arévalo, Pedro Jesús MaqueraLuque y Lucio Ticona-Carrizales

MÜLLER, Enrique. 2008. “Políticas en Turismo ¿̇ostenible?” In: R. de Camino, A. Ballestero \& J. Breitling, edits. Políticas de Recursos Naturales en Centroamérica: Lecciones, Posiciones y Experiencias para el Cambio. Universidad para la Paz. San José, Costa Rica.

NUGUER, Victoria; POWELL, Andrew. 2020. "Políticas y proyecciones para América Latina y el Caribe en tiempos del Covid-19" In: Ideas que cuentan BID. Available online. In: https://blogs.iadb.org/ideas-que-cuentan/es/ politicas-y-proyecciones-para-america-latina-y-el-caribe-en-tiemposdel-covid-19/. Consultation date: 16/12/2019.

OECD ESTUDIOS EN TURISMO. 2017. "OCDE Estudios en Turismo" In: Estudio de la Política Turística de México. Available online. In: https:// www.oecd.org/industry/tourism/MEXICO\%20TOURISM\%20 POLICY\%2OREVIEW_EXEC\%2OSUMM\%2OASSESSMENT\%20 AND\%2ORECOMMENDATIONS_ESP.pdf. Consultation date: 16/12/2019.

ORDÓÑEZ ANDRADE, Marta; MARCO NAVARRO, Flavia. 2005. Políticas de empleo en la planificación turística local de Ecuador. Herramientas para su formulación. CEPAL ONU. Santiago de Chile, Chile.

PEREIRA, C. 1999. "Políticas públicas no setor de turismo" In: Revista Turismo Em Análise. Vol. 10, No. 2, pp. 7-21.

SNYDER, Hannah. 2019. "Literature review as a research methodology: An overview and guidelines" In: Journal of Business Research. Available online. In: https://doi.org/10.1016/j.jbusres.2019.07.039. Consultation date: $16 / 04 / 2020$.

SUGANTHAN, N. 2019. “Covid-19” In: Jaffna Medical Journal. Available online. In: https://jmj.sljol.info/articles/abstract/10.4038/jmj. v31i2.72/. Consultation date: $10 / 04 / 2020$.

SUN, Pengfei; LU, Xiaosheng; XU, Chao; SUN, Wenjuan; PAN, Bo. 2020. "Understanding of COVID-19 based on current evidence" In: Journal of Medical Virology. Available online. In: https://doi.org/10.1002/ jmv.25722. Consultation date: 10/04/2020.

VELASCO GONZÁLES, María. 2014. “Gobernanza turística: ¿Políticas públicas innovadoras o retórica banal?” In: Cuaderno Virtual de Turismo. Vol. 14, No. 1, pp. 9-22.

VELASCO GONZÁLEZ, María. 2011. "La Política Turística. Una Arena de Acción Autónoma” In: Cuadernos de Turismo. No. 27, pp. 953-969. 
VELAVAN, Thirumalaisamy P; MEYER, Christian G. 2020. "The Covid-19 epidemic" In: Tropical Medicine and International Health. Available online. In: https://www.ncbi.nlm.nih.gov/pmc/articles/PMC7169770/. Consultation date: 10/04/2020.

XIE, Mingxuan; CHEN, Qiong. 2020. "Insight into 2019 novel coronavirus - an updated intrim review and lessons from SARS-CoV and MERS-CoV" In: International Journal of Infectious Diseases. Available online. In: https:// doi.org/10.1016/j.ijid.2020.03.071. Consultation date: 10/04/2020.

ZHANG, Carol; L'ESPOIR DECOSTA, Patrick; MCKERCHER, Bob. 2015. "Politics and tourism promotion: Hong Kong's myth making" In: Annals of Tourism Research. Pergamon, 54, pp. 156-171. 


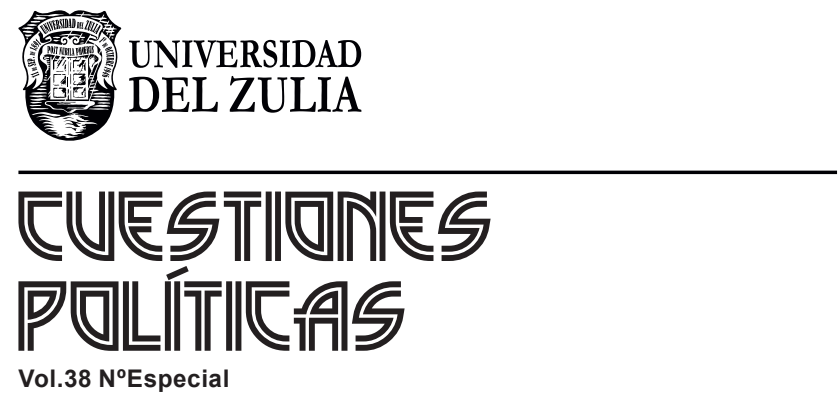

www.luz.edu.ve 